\title{
Ice velocity from static GPS observations along the transect from Zhongshan station to Dome A, East Antarctica
}

\author{
ZHANG Shengkai, ${ }^{1}$ E Dongchen, ${ }^{1}$ WANG Zemin, ${ }^{1}$ LI Yuansheng, ${ }^{2}$ JIN Bo, ${ }^{3}$ \\ ZHOU Chunxia ${ }^{1}$ \\ ${ }^{1}$ Chinese Antarctic Center of Surveying and Mapping, School of Geodesy and Geomatics, Wuhan University, \\ 129 Luoyu Road, Wuhan 430079, China \\ E-mail: zskai@whu.edu.cn \\ ${ }^{2}$ Polar Research Institute of China, Shanghai 200136, China \\ ${ }^{3}$ Chinese Arctic and Antarctic Administration, Beijing 100860, China
}

\begin{abstract}
Dome A, the highest point on the Antarctic ice sheet at just over $4000 \mathrm{~m}$ a.s.I., is located near the centre of East Antarctica. Chinese National Antarctic Research Expeditions have studied icesheet dynamics and mass balance along a traverse route from Zhongshan station to Dome A during the austral summers from $1996 / 97$ to $2004 / 05$. Nineteen GPS sites were occupied on at least two occasions at approximately $50 \mathrm{~km}$ intervals. The purpose of the surveys was to provide accurate ice-dynamics data. A dual-frequency GPS receiver was used and each site was occupied for 1-12 hours. GPS data were processed using GAMIT/GLOBK software, and horizontal accuracies were within $0.1 \mathrm{~m}$. Repeat GPS measurements provided ice velocities. The horizontal surface ice velocities increase from the summit of the ice sheet to the coast. In the Dome $A$ area, the velocities are $<10 \mathrm{~m} \mathrm{a}^{-1}$; in the plateau area, velocities range from 8 to $24 \mathrm{~m} \mathrm{a}^{-1}$ and reach about $98.2 \mathrm{~m} \mathrm{a}^{-1}$ at a site (LT980) near the coast. The flow directions are roughly perpendicular to the ice-sheet surface elevation contours, primarily toward the Lambert Glacier basin.
\end{abstract}

\section{INTRODUCTION}

Ice sheets play a major role in studies of global climate change and sea-level rise. The Antarctic ice sheet stores the majority of the Earth's fresh water, and the mass balance of the Antarctic ice sheet is an important climatic variable since any significant deviation from a balanced state will have an effect on global sea level (Meier, 1993; Alley and others, 2005). Mass-balance and other glaciological studies require knowledge of ice velocity, surface elevation, ice thickness and snow accumulation either from direct field measurements or via remote-sensing methods (Paterson, 1994). There are very few geodetic measurements of the above parameters in the interior of the East Antarctic ice sheet. Considering the difficulties of accessibility, the hostile environment and the logistic problems in Antarctica, the global positioning system (GPS) has become a standard tool for field measurement of ice kinematics and surface topography in Antarctica (Tabacco and others, 1998; Capra and others, 2000; King and others, 2000, 2007; Gudmundsson, 2006).

Dome A, the highest ice feature in Antarctica, is just over $4000 \mathrm{~m}$ a.s.I., located near the center of East Antarctica and approximately midway between the head of Lambert Glacier and the South Pole. In the framework of the International Trans-Antarctic Scientific Expedition (ITASE), the Chinese National Antarctic Research Expedition's (CHINARE) glaciological research program has concentrated on the traverse route between Zhongshan station and Dome A during the austral summers from 1996/97 to 2004/05 (Qin and others, 2000, 2004; Xiao and others, 2001, 2004; Zhang and others, 2002; Ren and others, 2004). The program has included studies of mass balance and ice temperature, meteorological measurements including automatic weather station installations, glacio-chemical studies of surface snow and shallow ice cores, and stratigraphy in snow pits and snow/firn cores.
Along the traverse route, GPS sites were established at approximately $50 \mathrm{~km}$ intervals. This paper describes the results of GPS surveys, which provide information on ice velocities along the transect from the coast to Dome A.

\section{FIELD EXPEDITIONS AND DATA PROCESSING}

The first expedition south from Zhongshan station extended to site DT001 (Fig. 1), $296 \mathrm{~km}$ inland, during the 1996/97 austral summer. Two GPS sites were set up at DT001. The

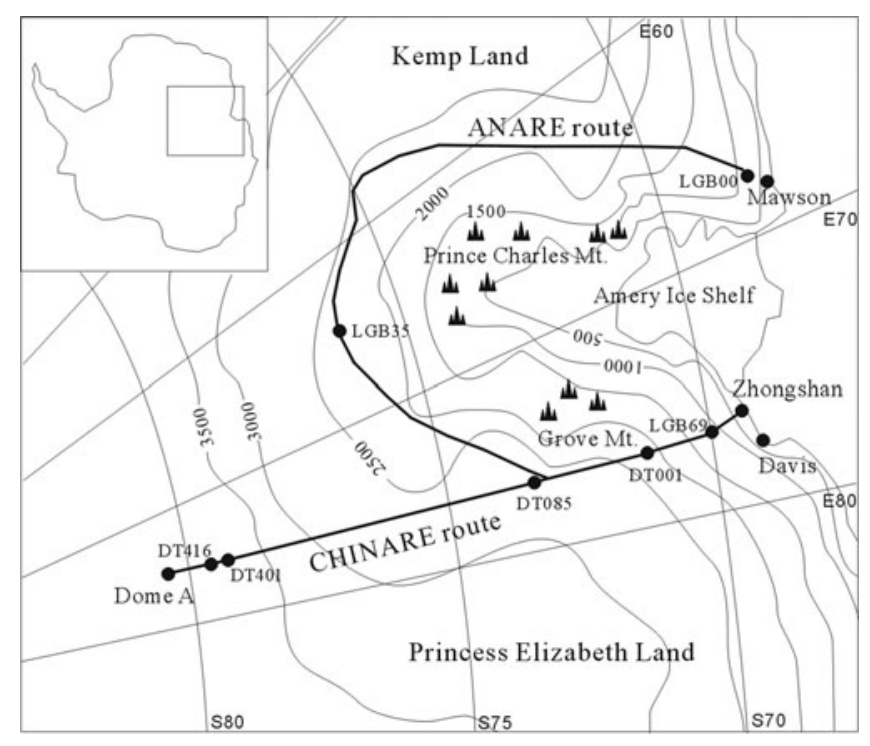

Fig. 1. Sketch map showing the route of the Chinese Antarctic inland traverse. 
Table 1. GPS observation information from $1996 / 97$ to $2004 / 05$ along the traverse route

\begin{tabular}{cccccccc}
\hline Site & $\begin{array}{c}\text { Distance from } \\
\text { Zhongshan } \\
\mathrm{km}\end{array}$ & Epoch & Year & Year & Year & Year & Year \\
\end{tabular}

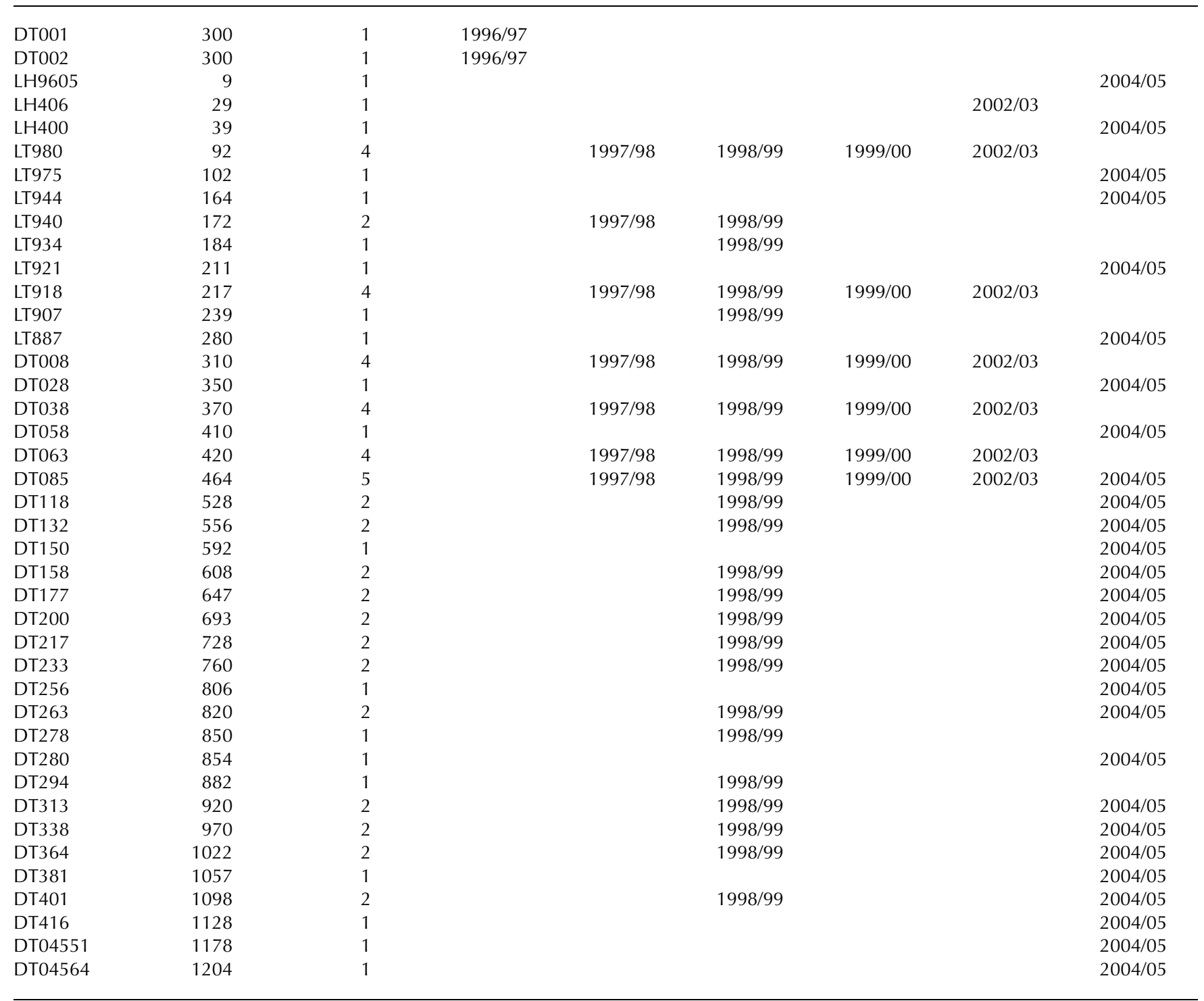

traverse was extended further southwards to site DT085, $464 \mathrm{~km}$ from Zhongshan station, during the 1997/98 field season. Seven GPS sites were set up along this section of the traverse. At each site, stainless-steel poles $3 \mathrm{~cm}$ in diameter and $3 \mathrm{~m}$ long were penetrated (vertically) into the snow to at least $1 \mathrm{~m}$ depth. The position was measured overnight using a dual-frequency GPS receiver. The satellite cut-off angle was set to $15^{\circ}$ and the sample interval was $15 \mathrm{~s}$. During the 1998/99 field season the traverse was extended further south to site DT416, $1128 \mathrm{~km}$ from Zhongshan station. The seven GPS sites set up in 1997/98 were reoccupied and 16 new GPS sites were established. During the 1999/2000 and 2002/03 field seasons, CHINARE carried out two expeditions to the Grove Mountains (Fig. 1); the traverse route was from Zhongshan station to DT085 and then turned west to the Grove Mountains (Dongchen and others, 2004, 2005). Along the traverse route, six GPS sites were reoccupied for several hours.
During the 2004/05 austral summer, the traverse was extended to the summit of Dome A, $1228 \mathrm{~km}$ from Zhongshan station. Snow accumulation rate and ice temperature were measured, and snow/firn ice cores were collected. Radio-echo sounding measurements and meteorological studies were conducted along the traverse route and at the summit of Dome A (Hou and others, 2007; Xu and others, 2007). The surface topography around the summit of Dome A, over an area of $60 \mathrm{~km}^{2}$, was measured using real-time kinematic GPS techniques (Zhang and others, 2007). Individual measurements of surface mass balance were made on bamboo poles spaced at $2 \mathrm{~km}$ intervals along the whole traverse route. The coordinates of the poles were recorded by a hand-held GPS navigator. The surface elevation profile of the traverse route was constructed from the GPS navigation data (Fig. 2). The topographic profile of the traverse indicates three sectors: an area extending about $200 \mathrm{~km}$ from Zhongshan station (slope area) with a steep 
Table 2. Horizontal velocities at GPS sites along the traverse route from Zhongshan station to Dome A

\begin{tabular}{|c|c|c|c|c|c|c|c|}
\hline \multirow[t]{2}{*}{ Site } & $\begin{array}{c}\text { Distance from } \\
\text { Zhongshan }\end{array}$ & Lat. (S) & Long. (E) & $\begin{array}{c}\text { Ellipsoidal } \\
\text { height }\end{array}$ & Time & Velocity & Azimuth \\
\hline & $\mathrm{km}$ & & & $\mathrm{m}$ & & $\mathrm{ma}^{-1}$ & \\
\hline LT980 & 92 & $70^{\circ} 07^{\prime} 49^{\prime \prime}$ & $76^{\circ} 35^{\prime} 31^{\prime \prime}$ & 1291 & 1997/98-2002/03 & 98.2 & 306 \\
\hline LT940 & 172 & $70^{\circ} 50^{\prime} 07^{\prime \prime}$ & $77^{\circ} 04^{\prime} 37^{\prime \prime}$ & 1870 & 1997/98-1998/99 & 17.5 & 324 \\
\hline LT918 & 217 & $71^{\circ} 13^{\prime} 18^{\prime \prime}$ & $77^{\circ} 23^{\prime} 42^{\prime \prime}$ & 2095 & 1997/98-2002/03 & 13.3 & 300 \\
\hline DT008 & 310 & $72^{\circ} 00^{\prime} 50^{\prime \prime}$ & $77^{\circ} 55^{\prime} 27^{\prime \prime}$ & 2373 & 1997/98-2002/03 & 24.5 & 296 \\
\hline DT038 & 370 & $72^{\circ} 32^{\prime} 30^{\prime \prime}$ & $77^{\circ} 35^{\prime} 06^{\prime \prime}$ & 2433 & 1997/98-2002/03 & 21.6 & 306 \\
\hline DT063 & 420 & $72^{\circ} 58^{\prime} 51^{\prime \prime}$ & $77^{\circ} 17^{\prime} 22^{\prime \prime}$ & 2546 & 1997/98-2002/03 & 8.9 & 310 \\
\hline DT085 & 464 & $73^{\circ} 22^{\prime} 05^{\prime \prime}$ & $77^{\circ} 00^{\prime} 42^{\prime \prime}$ & 2561 & 1997/98-2004/05 & 9.4 & 268 \\
\hline DT118 & 528 & $73^{\circ} 56^{\prime} 06^{\prime \prime}$ & $76^{\circ} 59^{\prime} 18^{\prime \prime}$ & 2643 & 1998/99-2004/05 & 17.7 & 277 \\
\hline DT132 & 556 & $74^{\circ} 10^{\prime} 41^{\prime \prime}$ & $77^{\circ} 00^{\prime} 36^{\prime \prime}$ & 2675 & 1998/99-2004/05 & 18.2 & 283 \\
\hline DT158 & 608 & $74^{\circ} 39^{\prime} 34^{\prime \prime}$ & $77^{\circ} 00^{\prime} 20^{\prime \prime}$ & 2738 & 1998/99-2004/05 & 10.7 & 291 \\
\hline DT177 & 647 & $74^{\circ} 59^{\prime} 42^{\prime \prime}$ & $76^{\circ} 58^{\prime} 03^{\prime \prime}$ & 2786 & 1998/99-2004/05 & 10.4 & 275 \\
\hline DT217 & 728 & $75^{\circ} 43^{\prime} 05^{\prime \prime}$ & $76^{\circ} 50^{\prime} 11^{\prime \prime}$ & 2811 & 1998/99-2004/05 & 12.8 & 270 \\
\hline DT233 & 760 & $76^{\circ} 00^{\prime} 20^{\prime \prime}$ & $76^{\circ} 56^{\prime} 18^{\prime \prime}$ & 2793 & 1998/99-2004/05 & 15.8 & 277 \\
\hline DT263 & 820 & $76^{\circ} 32^{\prime} 28^{\prime \prime}$ & $77^{\circ} 01^{\prime} 28^{\prime \prime}$ & 2824 & 1998/99-2004/05 & 17.1 & 316 \\
\hline DT313 & 920 & $77^{\circ} 25^{\prime} 43^{\prime \prime}$ & $76^{\circ} 59^{\prime} 45^{\prime \prime}$ & 3026 & 1998/99-2004/05 & 18.5 & 325 \\
\hline DT338 & 970 & $77^{\circ} 52^{\prime} 16^{\prime \prime}$ & $77^{\circ} 08^{\prime} 21^{\prime \prime}$ & 3154 & 1998/99-2004/05 & 7.6 & 316 \\
\hline DT364 & 1022 & $78^{\circ} 20^{\prime} 15^{\prime \prime}$ & $77^{\circ} 00^{\prime} 04^{\prime \prime}$ & 3373 & 1998/99-2004/05 & 3.0 & 36 \\
\hline DT401 & 1098 & $79^{\circ} 00^{\prime} 48^{\prime \prime}$ & $76^{\circ} 59^{\prime} 56^{\prime \prime}$ & 3736 & 1998/99-2004/05 & 1.3 & 9 \\
\hline
\end{tabular}

slope and height up to $2000 \mathrm{~m}$; a second area (plateau area) extending up to about $950 \mathrm{~km}$ with a gentle slope and height ranging from 2000 to $3100 \mathrm{~m}$; and the dome area in the last $300 \mathrm{~km}$ with height up to $4093 \mathrm{~m}$. The accuracy of elevation data during the 2004/05 traverse is higher than that of 1998/ 99, because the GPS navigation accuracy improved significantly once 'selective availability' was terminated on 1 May 2000 (Leick, 2004). This topographic profile is similar to the topographic profile from Terra Nova Bay to Dome C (slope area up to $250 \mathrm{~km}$, plateau area up to $900 \mathrm{~km}$, and dome area up to $1150 \mathrm{~km}$ ) (Frezzotti and others, 2002, 2005).

Along the 2004/05 traverse route, 28 GPS sites were measured including 13 repeated sites and 15 new sites. Along the first part of the traverse route from Zhongshan station to DT085, because the poles at the old GPS sites (at which ice velocities had previously been measured) were all buried, eight new sites were established. Along the second part of the traverse route from DT085 to Dome A, most of the old sites were remeasured; some of them were occupied overnight, and others occupied for 1-2 hours during short stops. There are 19 sites along the route that have been occupied on at least two occasions. GPS observation information from $1996 / 97$ to $2004 / 05$ is shown in Table 1.

The GPS data were processed using GAMIT/GLOBK software (King, 2002). During the data processing, (1) International GNSS Service (IGS) precise ephemerides were used; (2) several IGS stations around Antarctica (e.g. CAS1, DAV1, MAW1, MCM4, PALM, SYOG and VESL) were tightly constrained (within $1 \mathrm{~cm}$ ) at their ITRF2000 values, while the site along the traverse was loosely constrained (within $100 \mathrm{~m})$; (3) an elevation cut-off angle of $15^{\circ}$ was set; (4) antenna-phase centre variation corrections were applied; (5) the ionospheric-free linear combination of the L1 and L2 frequencies was used; (6) corrections were applied for both the solid-Earth and frequency-dependent tides; (7) the dry component of the zenith tropospheric delay was estimated by the Saastamoinen model; and (8) the wet component was estimated during the inversion, with zenith-delay adjustments every 2 hours. The GAMIT solutions were then combined using GLOBK software.

\section{RESULTS AND DISCUSSION}

Horizontal velocities at each of the 19 sites were extracted from the GAMIT/GLOBK solution. Horizontal uncertainties at the 19 sites were within $10 \mathrm{~cm}$. Elevation change in the region was also determined but will be reported elsewhere. Table 2 summarizes the velocity results of the 19 sites on the traverse. The surface ice-velocity vectors map is shown in Figure 3.

The horizontal surface velocity values are close to zero at the summit of Dome A and increase with distance from the summit. At Dome C, the ice surface at the poles closest to the summit moves horizontally by up to a few $\mathrm{mm} \mathrm{a}^{-1}$, while velocities $25 \mathrm{~km}$ from the summit are up to $0.211 \mathrm{~m} \mathrm{a}^{-1}$ (Vittuari and others, 2004). At Dome $F$ the surface ice-flow rate is $<10 \mathrm{ma}^{-1}$ in the inland region above $3000 \mathrm{~m}$ (Takahashi and others, 2003).

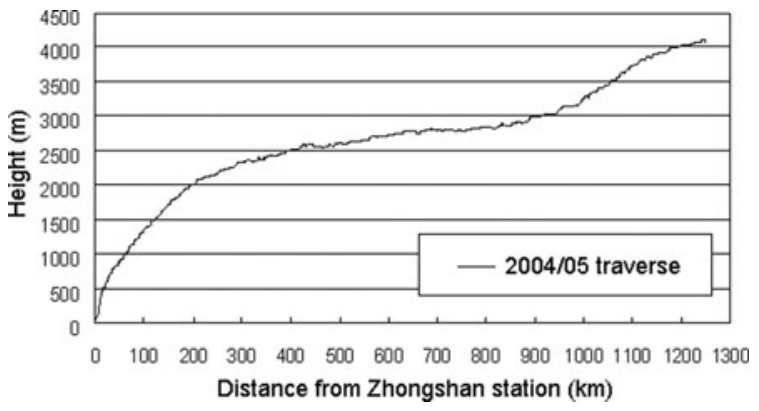

Fig. 2. Surface elevation profile of the traverse route from the coast to Dome A. 
Table 3. Horizontal velocities at GPS sites along the CHINARE and ANARE routes

\begin{tabular}{|c|c|c|c|c|c|c|c|c|}
\hline Site & $\begin{array}{l}\text { Distance from } \\
\text { Zhongshan } \\
\text { km }\end{array}$ & Lat. (S) & Long. (E) & $\begin{array}{c}\text { Ellipsoidal } \\
\text { height } \\
\text { m }\end{array}$ & Time & $\begin{array}{l}\text { Velocity } \\
\mathrm{ma}^{-1}\end{array}$ & Azimuth & Surveyor \\
\hline LGB72 & 68 & $69^{\circ} 55^{\prime} 15^{\prime \prime}$ & $76^{\circ} 29^{\prime} 36^{\prime \prime}$ & 1056 & 1993/94-1994/95 & 52.9 & 306 & ANARE \\
\hline LT980 & 92 & $70^{\circ} 07^{\prime} 49^{\prime \prime}$ & $76^{\circ} 35^{\prime} 31^{\prime \prime}$ & 1291 & $\begin{array}{c}\text { 1997/98-1998/99 } \\
\text { 1998/99-1999/2000 } \\
\text { 1999/2000-2002/03 }\end{array}$ & $\begin{array}{l}98.1 \\
98.4 \\
98.2\end{array}$ & $\begin{array}{l}306 \\
306 \\
306\end{array}$ & CHINARE \\
\hline LGB71 & 106 & $70^{\circ} 15^{\prime} 32^{\prime \prime}$ & $76^{\circ} 40^{\prime} 59^{\prime \prime}$ & 1406 & 1993/94-1994/95 & 62.6 & 318 & ANARE \\
\hline LGB70 & 142 & $70^{\circ} 34^{\prime} 33^{\prime \prime}$ & $76^{\circ} 51^{\prime} 59^{\prime \prime}$ & 1669 & 1993/94-1994/95 & 25.5 & 331 & ANARE \\
\hline $\begin{array}{l}\text { LT940* }^{*} \\
\text { LGB69* }^{*}\end{array}$ & 172 & $\begin{array}{l}70^{\circ} 50^{\prime} 07^{\prime \prime} \\
70^{\circ} 50^{\prime} 07^{\prime \prime}\end{array}$ & $\begin{array}{l}77^{\circ} 04^{\prime} 37^{\prime \prime} \\
77^{\circ} 04^{\prime} 40^{\prime \prime}\end{array}$ & $\begin{array}{l}1870 \\
1871\end{array}$ & $\begin{array}{l}1997 / 98-1998 / 99 \\
1993 / 94-1994 / 95\end{array}$ & $\begin{array}{l}17.5 \\
17.7\end{array}$ & $\begin{array}{l}324 \\
323\end{array}$ & $\begin{array}{l}\text { CHINARE } \\
\text { ANARE }\end{array}$ \\
\hline LGB68 & 202 & $71^{\circ} 05^{\prime} 43^{\prime \prime}$ & $77^{\circ} 17^{\prime} 19^{\prime \prime}$ & 2013 & 1993/94-1994/95 & 14.1 & 310 & ANARE \\
\hline LT918 & 217 & $71^{\circ} 13^{\prime} 18^{\prime \prime}$ & $77^{\circ} 23^{\prime} 42^{\prime \prime}$ & 2095 & $\begin{array}{c}\text { 1997/98-1998/99 } \\
\text { 1998/99-1999/2000 } \\
\text { 1999/2000-2002/03 }\end{array}$ & $\begin{array}{l}13.7 \\
13.7 \\
13.7\end{array}$ & $\begin{array}{l}300 \\
300 \\
300\end{array}$ & CHINARE \\
\hline LGB67 & 232 & $71^{\circ} 21^{\prime} 38^{\prime \prime}$ & $77^{\circ} 30^{\prime} 40^{\prime \prime}$ & 2152 & 1993/94-1994/95 & 14.8 & 287 & ANARE \\
\hline LGB66 & 262 & $71^{\circ} 37^{\prime} 14^{\prime \prime}$ & $77^{\circ} 43^{\prime} 50^{\prime \prime}$ & 2230 & 1993/94-1994/95 & 22.6 & 292 & ANARE \\
\hline LGB65 & 292 & $71^{\circ} 52^{\prime} 51^{\prime \prime}$ & $77^{\circ} 57^{\prime} 03^{\prime \prime}$ & 2341 & 1993/94-1994/95 & 22.5 & 295 & ANARE \\
\hline DT008 & 310 & $72^{\circ} 00^{\prime} 50^{\prime \prime}$ & $77^{\circ} 55^{\prime} 27^{\prime \prime}$ & 2373 & $\begin{array}{c}1997 / 98-1998 / 99 \\
\text { 1998/99-1999/2000 } \\
\text { 1999/2000-2002/03 }\end{array}$ & $\begin{array}{l}24.5 \\
24.4 \\
24.5\end{array}$ & $\begin{array}{l}296 \\
296 \\
296\end{array}$ & CHINARE \\
\hline LGB64 & 324 & $72^{\circ} 09^{\prime} 02^{\prime \prime}$ & $77^{\circ} 56^{\prime} 58^{\prime \prime}$ & 2367 & 1993/94-1994/95 & 24.2 & 297 & ANARE \\
\hline LGB63 & 354 & $72^{\circ} 24^{\prime} 38^{\prime \prime}$ & $77^{\circ} 43^{\prime} 23^{\prime \prime}$ & 2439 & 1993/94-1994/95 & 21.0 & 304 & ANARE \\
\hline DT038 & 370 & $72^{\circ} 32^{\prime} 30^{\prime \prime}$ & $77^{\circ} 35^{\prime} 06^{\prime \prime}$ & 2433 & $\begin{array}{c}\text { 1997/98-1998/99 } \\
\text { 1998/99-1999/2000 } \\
\text { 1999/2000-2002/03 }\end{array}$ & $\begin{array}{l}21.6 \\
21.5 \\
21.6\end{array}$ & $\begin{array}{l}306 \\
306 \\
306\end{array}$ & CHINARE \\
\hline LGB62 & 384 & $72^{\circ} 40^{\prime} 16^{\prime \prime}$ & $77^{\circ} 29^{\prime} 37^{\prime \prime}$ & 2483 & 1993/94-1994/95 & 21.3 & 306 & ANARE \\
\hline LGB61 & 412 & $72^{\circ} 55^{\prime} 52^{\prime \prime}$ & $77^{\circ} 15^{\prime} 47^{\prime \prime}$ & 2525 & 1993/94-1994/95 & 8.6 & 310 & ANARE \\
\hline DT063 & 420 & $72^{\circ} 58^{\prime} 51^{\prime \prime}$ & $77^{\circ} 17^{\prime} 22^{\prime \prime}$ & 2546 & $\begin{array}{c}\text { 1997/98-1998/99 } \\
\text { 1998/99-1999/2000 } \\
\text { 1999/2000-2002/03 }\end{array}$ & $\begin{array}{l}8.7 \\
9.0 \\
9.0\end{array}$ & $\begin{array}{l}310 \\
310 \\
310\end{array}$ & CHINARE \\
\hline LGB60 & 442 & $73^{\circ} 11^{\prime} 29^{\prime \prime}$ & $77^{\circ} 01^{\prime} 37^{\prime \prime}$ & 2595 & 1993/94-1994/95 & 7.6 & 265 & ANARE \\
\hline DT085 & 464 & $73^{\circ} 22^{\prime} 05^{\prime \prime}$ & $77^{\circ} 00^{\prime} 42^{\prime \prime}$ & 2561 & $\begin{array}{c}1997 / 98-1998 / 99 \\
1998 / 99-1999 / 2000 \\
1999 / 2000-2002 / 03 \\
2002 / 03-2004 / 05\end{array}$ & $\begin{array}{l}9.4 \\
9.3 \\
9.5 \\
9.4\end{array}$ & $\begin{array}{l}268 \\
268 \\
268 \\
268\end{array}$ & CHINARE \\
\hline LGB59 & 475 & $73^{\circ} 27^{\prime} 07^{\prime \prime}$ & $76^{\circ} 47^{\prime} 16^{\prime \prime}$ & 2549 & 1993/94-1994/95 & 10.6 & 276 & ANARE \\
\hline
\end{tabular}

"Site LT940 and site LGB69 are the same site.

The velocity increases from $1.3 \mathrm{ma}^{-1}$ at site DT401 $\left(150 \mathrm{~km}\right.$ from the summit of Dome A) to $3.0 \mathrm{ma}^{-1}$ at site DT364 ( 230 km from the summit of Dome A). The velocity at site DT338 (3154 m a.s.I.; $280 \mathrm{~km}$ from the summit) is $7.6 \mathrm{ma}^{-1}$, while it reaches $18.5 \mathrm{ma}^{-1}$ at DT313 (3026 m a.s.l.; $330 \mathrm{~km}$ from the summit). So the velocity in the dome region, which is above $3100 \mathrm{~m}$ and within about $300 \mathrm{~km}$ of the summit, is $<10 \mathrm{~m} \mathrm{a}^{-1}$. The flow directions at these sites are consistent with downslope (perpendicular to the elevation contours) motion of the ice sheet. In forthcoming field seasons, we plan to establish a strain network in the Dome A region for the study of ice dynamics, which will provide fiducial control for synthetic aperture radar (SAR) interferometry and balance-velocity computation, and will be an important pre-site survey for deep ice drilling.
In the plateau area of the traverse route, the velocities range from 8 to $24 \mathrm{~m} \mathrm{a}^{-1}$, and ice flows towards the Lambert Glacier basin (LGB). The first part of the route from Zhongshan station to DT085 is partly coincident with the Australian National Antarctic Research Expeditions (ANARE) traverse route surrounding the LGB during the early 1990s (Fig. 1). The ice-flow velocities along the ANARE traverse line varied between 10 and $25 \mathrm{~m} \mathrm{a}^{-1}$ (Manson and others, 2000; Kiernan, 2001), agreeing with our results (Table 3). The velocity differences during the three periods (1997/981998/99, 1998/99-1999/2000 and 1999/2000-2002/03) at the six sites (LT980, LT918, DT008, DT038, DT063 and DT085) are very small (within $0.3 \mathrm{~m} \mathrm{a}^{-1}$ ) and the flow directions are the same. The velocity difference between 1993/94-1994/95 and 1997/98-1998/99 at LT940 and LGB69 is $0.2 \mathrm{~m} \mathrm{a}^{-1}$. Considering the calculation uncertainty, 


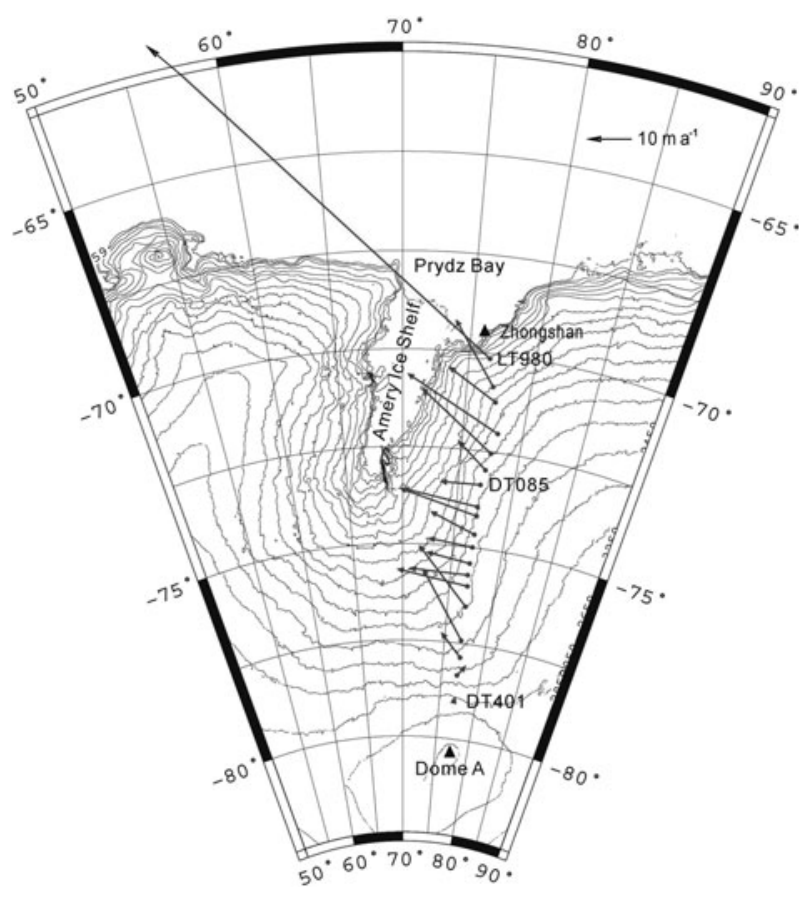

Fig. 3. Vector map of surface ice flow along the traverse from Zhongshan station to Dome A. (Elevation contours derived from the RAMP DEM.)

the eastern edge of the LGB is considered to have been in balance since the 1990s. Similar ice-flow measurements have been performed over other glacier basins in Antarctica. For instance, the surface flow velocity is $\sim 20 \mathrm{~m} \mathrm{a}^{-1}$ in the middle part of the Shirase Glacier drainage basin at about $2500 \mathrm{~m}$ a.s.I. in the Dronning Maud Land ice sheet (Takahashi and others, 2003).

The maximum ice velocity was found in the coastal icesheet regions where the velocity reaches $98.2 \mathrm{ma}^{-1}$ at site LT980 (92 km from Zhongshan station). The velocities at sites LGB72 and LGB71 on the steep coastal slopes of the eastern side of the LGB are respectively 52.9 and $62.6 \mathrm{~m} \mathrm{a}^{-1}$.

\section{CONCLUSION}

We have detailed the measurement of ice-surface movement along the traverse route from Zhongshan station to Dome A, the highest point on the Antarctic ice sheet. The horizontal ice-surface velocities increase from near zero at the summit to several tens of $\mathrm{m} \mathrm{a}^{-1}$ near the coast. The flow directions are roughly perpendicular to the surface elevation contours, most of the vectors indicating flow towards the LGB. Our measurements are in good agreement with the ANARE measurements in the lower section of the CHINARE traverse, where the two sets overlap (see Fig. 4). In addition, the measurements show similar characteristics to those in other Antarctic glacier drainage basins.

The ice surface velocity measurements in this region will provide fiducial control for remote-sensing analysis. Future repeat GPS measurements will be used to validate the present ice-flow conditions. Radio-echo sounding was also carried out along the traverse route; results will be published elsewhere. Ice thickness and bedrock topography will provide further explanation for the ice-velocity variation along the transect. Combining the data of ice velocity, ice thickness and snow accumulation will be helpful in the

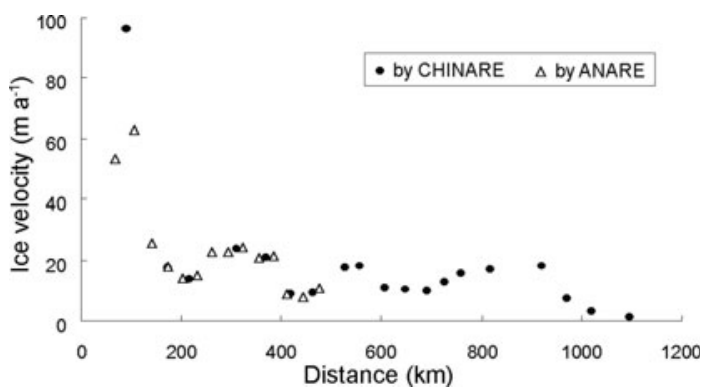

Fig. 4. Surface ice velocity along both CHINARE and ANARE traverses.

study of ice dynamics, and so will be useful in mass-balance assessment of the ice sheet.

\section{ACKNOWLEDGEMENTS}

We thank the members of the inland ice-sheet teams of CHINARE from 1996/97 to 2004/05. The Massachusetts Institute of Technology and the US National Snow and Ice Data Center provided the GAMIT/GLOBK software package and the RADARSAT-1 Antarctic Mapping Mission digital elevation model (RAMP DEM) respectively. We appreciate the helpful comments of Xiao Cunde and two anonymous reviewers. This work was supported by State Bureau of Surveying and Mapping (No. 1469990711109-1), Chinese Arctic and Antarctic Administration (No. 20070206) and the National Science Foundation of China (No. 40606002).

\section{REFERENCES}

Alley, R.B., P.U. Clark, P. Huybrechts and I. Joughin. 2005. Icesheet and sea-level changes. Science, 310(5747), 456-460.

Capra, A., R. Cefalo, S. Gandolfi, G. Manzoni, I.E. Tabacco and L. Vittuari. 2000. Surface topography of Dome Concordia (Antarctica) from kinematic interferential GPS and bedrock topography. Ann. Glaciol., 30, 42-46.

Dongchen, E., C. Zhou and M. Liao. 2004. Application of SAR interferometry on DEM generation of the Grove Mountains. Photogramm. Eng. Remote Sens., 70(10), 1145-1149.

Dongchen, E., S. Zhang, L. Yan and F. Li. 2005. The establishment of GPS control network and data analysis in the Grove Mountains, East Antarctica. SCAR Rep. 23, 46-49.

Frezzotti, M., S. Gandolfi, F. La Marca and S. Urbini. 2002. Snow dunes and glazed surfaces in Antarctica: new field and remotesensing data. Ann. Glaciol., 34, 81-88.

Frezzotti, M. and 13 others. 2005. Spatial and temporal variability of snow accumulation in East Antarctica from traverse data. J. Glaciol., 51(172), 113-124.

Gudmundsson, G.H. 2006. Fortnightly variations in the flow velocity of Rutford Ice Stream, West Antarctica. Nature, 444(7122), 1063-1064.

Hou, S., Y. Li, C. Xiao and J. Ren. 2007. Recent accumulation rate at Dome A, Antarctica. Chinese Sci. Bull., 52(3), 428-431.

Kiernan, R. 2001. Ice sheet surface velocities along the Lambert Glacier basin traverse route. Antarct. CRC Res. Rep. 23.

King, R.W. 2002. Documentation for the GAMIT GPS analysis software, release 10.05. Cambridge, MA, Massachusetts Institute of Technology.

King, M., L. Nguyen, R. Coleman and P.J. Morgan. 2000. Strategies for high precision processing of GPS measurements with application to the Amery Ice Shelf, East Antarctica. GPS Solutions, 4(1), 2-12. 
King, M.A., R. Coleman, P.J. Morgan and R.S. Hurd. 2007. Velocity change of the Amery Ice Shelf, East Antarctica, during the period 1968-1999. J. Geophys. Res., 112(F1), F01013. (10.1029/ 2006JF000609.)

Leick, A. 2004. GPS satellite surveying. Third edition. New York, John Wiley \& Sons.

Manson, R., R. Coleman, P. Morgan and M. King. 2000. Ice velocities of the Lambert Glacier from static GPS observations. Earth Planets Space, 52(11), 1031-1036.

Meier, M.F. 1993. Ice, climate, and sea level: do we know what is happening? In Peltier, W.R., ed. Ice in the climate system. Berlin, etc., Springer-Verlag, 141-160. (NATO ASI Series I: Global Environmental Change 12.)

Paterson, W.S.B. 1994. The physics of glaciers. Third edition. Oxford, etc., Elsevier.

Qin, D. and 8 others. 2000. Primary results of glaciological studies along an $1100 \mathrm{~km}$ transect from Zhongshan station to Dome A, East Antarctic ice sheet. Ann. Glaciol., 31, 198-204.

Qin, D. and 6 others. 2004. Snow surface height variations on the Antarctic ice sheet in Princess Elizabeth Land, Antarctica: 1 year of data from an automatic weather station. Ann. Glaciol., 39, 181-187.

Ren, J., J. Sun and D. Qin. 2004. Preliminary results of ionic concentrations in snow pits along the Zhongshan-Dome A traverse route, Antarctica. Ann. Glaciol., 39, 155-160.

Tabacco, I.E., A. Passerini, F. Corbelli and M.R. Gorman. 1998.
Determination of the surface and bed topography at Dome C, East Antarctica. J. Glaciol., 44(146), 185-191.

Takahashi, S., R. Naruse, F. Nishio and O. Watanabe. 2003. Features of ice sheet flow in East Dronning Maud Land, East Antarctica. Polar Meteorol. Glaciol., 17, 1-14.

Vittuari, L. and 6 others. 2004. Space geodesy as a tool for measuring ice surface velocity in the Dome $\mathrm{C}$ region and along the ITASE traverse. Ann. Glaciol., 39, 402-408.

Xiao, C., J. Ren, D. Qin, H. Li, W. Sun and I. Allison. 2001. Correspondence. Complexity of the climatic regime over the Lambert Glacier basin of the East Antarctic ice sheet: firn-core evidences. J. Glaciol., 47(156), 160-162.

Xiao, C., I. Allison, J. Ren, D. Qin, M. Zhang and Z. Li. 2004. Meteorological and glaciological evidence for different climatic variations on the east and west sides of the Lambert Glacier basin, Antarctica. Ann. Glaciol., 39, 188-194.

Xu, J., S. Hou, J. Ren and J.R. Petit. 2007. Insoluble dust in a new core from Dome Argus, central East Antarctica. J. Glaciol., 53(180), 154-156.

Zhang, M.J. and 6 others. 2002. A continuous 250-year record of volcanic activity from Princess Elizabeth Land, East Antarctica. Antarct. Sci., 14(1), 55-60.

Zhang, S., E. Dongchen, Z. Wang, C. Zhou and Q. Shen. 2007. Correspondence. Surface topography around the summit of Dome A, Antarctica, from real-time kinematic GPS. J. Glaciol., 53(180), 159-160. 